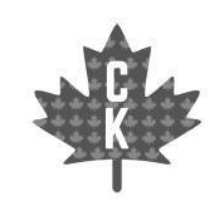

JESSICA MARSELLA'

\title{
Examining the Subjugation of Indigenous Women through Community Partnerships with Extractive Industries
}

\begin{abstract}
Integration into the capitalist market creates an opportunity for Indigenous communities to relinquish interdependent relationships with the Canadian state by commodifying natural resources to subsidize funding. Corporate partnerships offer Indigenous communities an opportunity for economic development to help alleviate conditions of poverty; however, the potential benefits are not reaching all members of the communities equally. Rather, extractive developments on Indigenous territories are creating new and complex challenges for Indigenous women. This paper examines the current and historical legacies of colonization within Canada that have excluded and oppressed Indigenous women, and have made Indigenous communities dependent on colonial processes to improve socioeconomic disparities. The legacies of colonization, the patriarchal foundations of capitalism, and the transient nature of extractive developments disproportionately harm Indigenous women, making corporate partnerships an unsustainable option to maintain Indigenous independence from the Canadian State.
\end{abstract}

Keywords: Indigenous rights, Indigenous women, Resource extraction, Community development, Colonization, Capitalism

\section{Résumé}

L'intégration au marché capitaliste offre aux communautés indigènes la possibilité de renoncer à leurs relations d'interdépendance avec le Canada en commercialisant les ressources naturelles pour subventionner le financement. Les partenariats d'entreprises offrent aux communautés indigènes une opportunité de développement économique pour aider à atténuer les conditions de pauvreté ; cependant, les bénéfices potentiels ne touchent pas tous les membres des communautés de manière égale. Au contraire, les développements extractifs sur les territoires indigènes créent des défis nouveaux et complexes pour les femmes indigènes. Cet article examine les héritages actuels et historiques de la colonisation au Canada, qui ont exclu et ont opprimé les femmes autochtones, et ont rendu les communautés autochtones dépendantes des processus coloniaux pour améliorer les disparités socio-économiques. L'héritage de la colonisation, les fondements patriarcaux du capitalisme et la nature transitoire des développements extractifs nuisent de manière disproportionnée aux femmes autochtones, faisant des partenariats d'entreprises une option non viable pour maintenir l'indépendance des autochtones vis-àvis du Canada.

Mots clés: droits des autochtones, femmes autochtones, extraction des ressources, développement communautaire, colonisation, capitalisme, autonomie gouvernementale

\footnotetext{
' York University, Ontario.

The author of this paper is a white settler residing on the traditional territories of the Mississauga's of the New Credit. This author recently completed their Bachelor of Social Work degree from York University, with research focused primarily on intersectional oppression as it relates to Indigenous Women in Canada. This article was written as a research paper, and is not intended to appropriate or critique the stories, challenges, or decisions of Indigenous Peoples and Communities.
} 
Interdisciplinary Approaches to Canadian Studies

The effects of corporate partnerships with Indigenous nations have been a longstanding point of contention within social and political landscapes. While certain discourse suggests corporate partnerships based upon resource extraction will help support the future of Indigenous self-government (Slowey, 2008, p. 17), and there are undoubtedly a number of opportunities for economic advancements, the consequences of large industries basing projects within Indigenous communities disproportionately harm the women who live and work there. Dawn Martin-Hill (2008) argues that Indigenous women have borne the brunt of colonialism in Canada as the patriarchal structures of colonial powers have disproportionately targeted women through violence, displacement, and the destruction of family and community similar to the current instances of extraction developments on Indigenous land (p. 121). The patriarchal nature of capitalism often excludes women from lucrative positions within the developments, while the transient workforces associated with extraction projects pose a direct threat to the physical safety of Indigenous women and girls living within the proximity of the worksites. Using examples from the Lubicon Cree and Qamani'tuaq Communities, along with current and historical examples of Canada's colonial legacy and social context, this paper will argue that corporate partnerships, specifically, those that seek to extract and commodify natural resources, mimic colonial relationships through patriarchal capitalism, offering unequal benefits and disproportionately harming women within the affected communities.

To gain a full understanding of the ways in which Indigenous women have historically and continue to be disproportionately affected by colonization, one must look at the history of colonial patriarchy within Canada. European colonizers brought ideas of male domination paired with the expectation of women as subservient and domestic to Indigenous Nations within Canada. Upon colonization, Europeans violently imposed these ideas onto Indigenous women despite the autonomous and sacred positions they took up within their own communities (Stevenson, 1999, p. 73). Furthermore, Anderson (2016) states that "through colonization and the work of missionaries, women were excluded and handed a marginal role" ( $p$. 55).

Furthermore, Martin-Hill (2008, p. 126) argues that through the systemic removal of children from Indigenous communities, Indigenous women are robbed of their most basic rights. When examining historical and contemporary child apprehension methods, such as residential schooling which began at the time of confederacy and had operational federally funded schools until 1996, the Sixties Scoop, which occurred from the year 1960 into the early 1980's (Blackstock, 2009, pp. 29-30) and, the current overrepresentation of Indigenous children within
Canadian child welfare systems, it is clear the State disproportionately and strategically targets Indigenous families (Vowel, 2016, p. 182). According to 2016 Canadian census data, while Indigenous children make up only $7.7 \%$ of the national population of children under the age of fourteen, they account for $52.2 \%$ of Canadian children in foster care (Indigenous Services Canada, 2019). Blackstock (2007) explains that despite the shocking statistics, Indigenous children are far less likely to be reported to child welfare services for instances of sexual, emotional, or physical abuse than their non-indigenous counterparts. However, Indigenous families are twice as likely to be reported for poverty-related neglect, such as inadequate food and housing (p. 75). Based on these statistics, it is evident that Indigenous children are vastly overrepresented within child welfare not because they are at greater risk in their homes, but rather it is because their families are at greater risk of experiencing systemic racism and systems of poverty (Blackstock, 2007, p. 76). Martin-Hill (2008) argues that for Indigenous women, to be powerless is to be without your family (p. 124). The calculated dismantling of family and community has and continues to disproportionately affect women, stripping women of their important roles as mothers and caregivers (Martin-Hill, 2008, p. 122).

Capitalism constructs a new layer of intersectional oppression for Indigenous women. Werlhof, (2007) takes on the concept of patriarchal capitalism, and the ways in which capitalism undermines, undervalues, and oppresses women. Patriarchal capitalism accentuates the value put on physical labor and accumulation of capital, and the devaluing of social production and caregiver roles. Thus capitalism relies upon patriarchal social order and the systematic devaluing of women in order to succeed in maximizing profits. Additionally, capitalism reinforces colonial gender binaries and gender roles, where men are expected to work and make money in the public sector, and women are expected to work in the home with no monetary wages, empowering men in a system that values economy over all else.

The social and cultural impacts of major capitalist endeavors within Indigenous Nations are necessary to understand the disproportionate impact extractive industry partnerships have on the women in Indigenous communities. Rauna Kuokkanen (2011) states that neoliberalism fundamentally contradicts traditional Indigenous cultures and teachings by treating the land as a commodity rather than existing in relationship to the Earth (p. 289). When the relationship with the Earth is being broken down, it threatens the essence of Indigenous communities and cultures. In an interview with Sara Bernard, Melina Laboucan-Massimo, a member of the Lubicon Cree First Nation explains that when systems like capitalism 
Interdisciplinary Approaches to Canadian Studies

that are based upon power and dominance are favored within a community, it is a reflection of how people in the community are being treated (Laboucan-Massimo in Bernard, 2015). Laboucan-Massimo states "violence against the Earth begets violence against women" (2015, para. 3). Extractive practices break down sacred relationships between women and the land and put a strain on various communities and their respective cultures. In the instance of the Lubicon Cree, it is the women who suffer the most from the environmental damage brought on by resource extraction by industries like oil and lumber on their territories (Martin-Hill, 2008, p. 150). In 1992, the Lubicon Women's Circle made a public statement to express the anguish the environmental damage brought upon themselves and their communities (Martin-Hill, 2004, p. 317). The Lubicon Women's Circle explained that their children were sick from the poor air quality and water pollution. Consequently, fish and game populations were depleted, and the remaining animals for consumption were also sick and diseased - the bush that provided them their traditional way of life was destroyed (Martin-Hill, 2004, p. 319). These women testified that as living conditions became direr, families became broken, while violence and substance abuse increased. The families and cultures these women have worked so hard to nurture and protect were being dismantled by corporate greed.

In addition to the attack on culture, and the devastating environmental impacts, extractive developments often require the employment of transient workers, which poses a direct threat to Indigenous women and girls. The National Inquiry into Missing and Murdered Indigenous Women and Girls (2014) includes a regional cumulative-effects assessment of hydroelectric development in Manitoba that linked the arrival of a largely male transient workforce to an influx of sexual abuse against Indigenous women; as well as a report by the Northern Health and Provincial Health Services Authority of British Columbia that identifies a relationship between crime rates and resource extracting, specifically including physical and sexual assaults against women (2014, p. 586). The inquiry suggests that the transient nature of the workforces associated with resource extraction developments poses a threat to the physical safety of Indigenous women and girls (2014, p. 585).

Extractive developments are posing new and complex threats to women in Indigenous communities. Similar to original colonial efforts, current practices destabilize women's traditional roles in their communities and pose an immediate threat to their physical safety (National Inquiry into Missing and Murdered Indigenous Women and Girls, 2014, p. 585). In this regard, corporate expansion onto Indigenous territory is nothing less than a continuing colonial effort performed under the guise of providing financial supports to Indigenous communities.

Given the patriarchal nature of capitalist structures, the opportunities for monetary profits from corporate partnerships are inequitably divided among the community, specifically between men and women. Extractive industries often offer women fewer skilled and high-paying positions than men, employing them in more gendered roles which offer significantly lower wages than the trade-oriented positions offered primarily to men (Manning, et al. 2018, pp. 5-6). This report titled A Literature Synthesis Report on the Impacts of Resource Extraction for Indigenous Women (2018) also includes a study of Inuit Women in Qamani'tuaq employed at the Meadowbank Gold Mine. This report found that women working for the mine were more likely to hold temporary and casual positions, while men primarily held full-time positions with the project (Manning, et al. 2018, pp. 5-8). They also found that the shift work, and 'fly in fly out' arrangements of the job kept women from their children and families for prolonged periods of time - which created an increase in family conflict and breakdowns in relationship. Additionally, the lack of childcare while working was one of the most common reasons women in Qamani'tuaq left their positions at Meadowbank Gold (Manning, et al. 2018, p. 6).

In addition to the lack of equitable and prosperous job opportunities for women, the 2018 study concludes that Indigenous women working at resource extraction sites in any capacity are often subjected to disproportionate rates of racialized and sexualized harassment and violence within the workplace (Manning, et al, 2018, p. 7). There are several distinct aspects that make Indigenous women particularly susceptible to this type of violence and harassment. First, the intersectional identities of Indigenous women paired with low-power positions within the workplace hierarchy makes these women especially vulnerable to men, specifically white men, who tend to maintain high-powered positions. Second, the report adds that in the instance of Qamani'tuaq Inuit Women working for Meadowbank Gold Mine, women working as cleaners or housekeepers are given tasks that require them to work within male sleeping quarters, placing them at a much greater risk for sexual harassment and assault (Manning, et al. 2018, p. 7). Violence and harassment are also common reasons for women leaving their jobs at Meadowbank Gold Mine.

The temporary nature of extraction developments also causes great distress for Indigenous women, who reported feeling anxious about what would happen to their families and communities once the projects they depend on for employment and income are shut down (Manning, et al. 2018, p. 9). Apart from the loss of income when the development is 
Interdisciplinary Approaches to Canadian Studies

complete, there are residual effects of the incomerelated inflation on necessities like food and housing even after the project is shut down. Many Indigenous women experience anxiety regarding the inflated cost of living and how this will affect their lives and wellbeing after projects are shut down and unemployment rates rise (Rixen and Blangy, 2016, pp. 297-312). While agreements between corporations and Indigenous communities promise to provide economic opportunities and solutions for the communities involved, a 2016 study on Inuit population movements and inequalities highlight the fact that pre-existing socioeconomic inequalities can leave many families within land claim areas in poorer living conditions than they had endured prior to agreements due to rising social costs, unmet expectations, inadequate social recourses and a rapidly changing social landscape (Dombrowski et al. 2016, p. 786) with women once again bearing the brunt of the damage caused. While Indigenous women who are employed by resource extraction development projects receive less opportunity for economic mobility and are often subjected to hostile and dangerous work environments created by their male co-workers, women who remain at home with partners and family members employed in resource extraction have to take on an increased caregiver burden within their families and communities (Manning, et al. 2018, p. 6). Evidently, Indigenous men and women are not being offered equal benefits through partnerships with resource extraction companies.

Certain scholarly discourse argues that corporate partnerships are a viable solution to provide Indigenous communities with economic benefits outside of the scope of the State (Craik, Gardner \& McCarthy, 2017, p. 379), providing an opportunity to move beyond state dependency. These neoliberal pursuits offer Indigenous communities control over the profits they receive from extraction partnerships, which offer hope for economic mobility, and relief from impoverished conditions that are unfortunately common on Indigenous Reserves. However, many of the relationships are only offered through terms that mimic colonial models (Irlbacher-Fox, 2010, p. 3). There is an unequal power relationship between large corporations and the Indigenous communities from which they wish to extract resources. This aspect is similar to the way in which colonizers seized land for economic expansion through violence against Indigenous Peoples, forcing them off their territories using weaponry and means that Indigenous Peoples did not have access to (Cormier, 2017, p. 45). The extraction companies have unlimited funds and massive project budgets, yet they aim to profit off of Indigenous Communities with unstable economies and lack of basic resources and infrastructure. Although there is a consultation process when piloting projects, many Indigenous Peoples involved with the consults feel there is a lack of mutual respect and meaningful collaboration, effectively undermining the communities' involvement in decision making while the corporations take on an overpowering paternalistic approach (Dylan, Smallboy \& Lightman, 2014, p. 75).

Regardless, developments that ravish the land and radically alter and deplete the natural landscape are seen as one of the few realistic and attainable solutions to poverty and state dependency, as modern methods of self-government are often founded upon the capitalist market economy (Kuokkanen, 2011, p. 275). Although self-governance is an opportunity for Indigenous communities to operate independently from the Canadian State, many nations maintain this financial independence by integrating into the global market and commodifying their resources in order to subsidize their income, creating a situation of marketbased self-government (Kuokkanen, p. 280). IrlbacherFox defines self-government as the extent to which the Canadian government is willing to grant Indigenous communities' authority over a range of areas that will determine their way of life and is circumscribed by Canadian law (Irlbacher-Fox, 2010, p. 7). Indigenous Peoples are forced to accommodate the rules and processes of the colonial state in order to achieve outcomes that do not represent their best interests (Salée and Lévesque, 2010, p. 104). Aside from the social detriments, market-based self-government -and extraction-based partnerships in general- shift dependency from the state into dependency on corporations. The temporary nature of extractive developments does not provide long-term economic relief, meaning communities will have to make multiple deals, which will further damage the land and intrinsically link the economic success of community members to corporate developments. Additionally, engaging in agreements with extractive industries is not only ecologically unsustainable, but these agreements also bring unequal opportunity and disproportionate harm to the women living within the community (Kuokkanen, 2011, p. 279).

The purpose of this essay is not to argue that corporate partnerships do not hold any value within Indigenous efforts towards self-government, nor is it to say that the communities who choose to engage with extraction developments are not acting in the best interest of their community. The purpose is however to argue that these relationships are born out of necessity created by the colonial state, and therefore, cannot be an act of decolonization, or even sovereignty over the land. The appropriation and destruction of land, and harm brought onto women in the community replicates the damage done by colonial efforts of the past and does not fully offer the benefits promised. Devaluing the land and undermining earth-based ideology is a type of forced assimilation, and resource extraction calls for communities to allow large corporations to 
Interdisciplinary Approaches to Canadian Studies

compromise their relationship with the Earth in order to receive financial gain (George, 2019, p. 76).

Evidently, relationships between Indigenous communities and extractive industries are complex and multi-faceted, and no single solution will work for every community, however corporate partnerships formed out of economic necessity, that degrade the land and disproportionately harm Indigenous women do not appear to be an equitable, de-colonial solution for Indigenous communities striving for independent selfgovernment.

\section{References}

Anderson, Kim. (2016) A recognition of being: Reconstructing Native womanhood. Canadian Scholars' Press.

Bernard, S. (2016, April 04). Making the connections on tar-sands pollution, racism, and sexism. Retrieved December 07, 2020, from https://grist.org/climate-energy/making-theconnections-on-tar-sands-pollution-racismand-sexism/

Blackstock, C. (2007). Residential schools: Did they really close or just morph into child welfare Indigenous Law Journal, 6(1), 71-78.

Blackstock, C. (2009). The occasional evil of angels: Learning from the experiences of aboriginal peoples and social work. First Peoples Child and Family Review.

Cormier, P. (2017). British Colonialism and Indigenous Peoples: The Law of Resistance-ResponseChange. Peace Research, 49(2), 39-60. Retrieved February 25, 2021, from http://www.jstor.org.ezproxy.library.yorku.ca /stable/44779906

Craik, N., Gardner, H., \& McCarthy, D. (2017). Indigenous-corporate private governance and legitimacy: Lessons learned from impact and benefit agreements. Resources Policy, 52, 379-388.

Dombrowski, K., Habecker, P., Gauthier, G. R., Khan, B., \& Moses, J. (2016). Relocation redux: Labrador Inuit population movements and inequalities in the land claims era. Current Anthropology, 57(6), 785-805. doi:10.1086/689210

Dylan, A., Smallboy, B., \& Lightman, E. (2014). "Saying no to resource development is not an option": Economic development in Moose Cree First
Nation. Journal of Canadian Studies/Revue

d'études Canadiennes, 47(1), 59-90.

doi:10.1353/jcs.2014.0009

George, C. T. (2019). Decolonize, then indigenize: Critical insights on decolonizing education and indigenous resurgence in Canada. Antistasis, 9(1), 73-95. Retrieved from http://ezproxy.library.yorku.ca/login?url=http s://www-proquestcom.ezproxy.library.yorku.ca/docview/23097 51341? accountid=15182

Indigenous Services Canada. (2019, September 10). Reducing the number of Indigenous children in care. Retrieved from https://www.sacisc.gc.ca/eng/1541187352297/1541187392 851

Irlbacher-Fox, S. (2010). Finding dahshaa: Selfgovernment, social suffering, and aboriginal policy in Canada. https://ebookcentral.proquest.com/lib/york/r eader.action?doclD=3412649

Kuokkanen, R. (2011). From indigenous economies to market-based self-governance: A feminist political economy analysis. Canadian Journal of Political Science/Revue canadienne de science politique, 44(2), 275-297.

Manning, S., Nash, P., Levac, L., Stienstra, D., \& Stinson, J. (2018). A literature synthesis report on the impacts of resource extraction for Indigenous women. Ottawa: Canadian Research Institute for the Advancement of Women.

Martin-Hill, D. (2004). Resistance, determination and perseverance of the Lubicon Cree women. The way of development: Indigenous peoples, life projects and globalization.

Martin-Hill, D. (2008). The Lubicon Lake Nation: indigenous knowledge and power. University of Toronto Press.

National Inquiry into Missing and Murdered Indigenous Women and Girls. (2019). Reclaiming power and place. The final report of the national inquiry into missing and murdered indigenous women and girls. The National Inquiry. https://www.mmiwg-ffada.ca/wpontent/uploads/2019/06/Final Report Vol 1 a-1.pdf

Rixen, A., \& Blangy, S. (2016). Life after Meadowbank: Exploring gold mine closure scenarios with the residents of Qamini'tuaq (Baker Lake), 
Interdisciplinary Approaches to Canadian Studies

Nunavut. Extractive Industries and Society, 3(2), 297-312. doi:10.1016/j.exis.2015.09.003

Salée, D. \& Lévesque, C. (2010). Representing Aboriginal Self-Government and First Nations/State Relations: Political Agency and the Management of the Boreal Forest in Eeyou Istchee. International Journal of Canadian Studies / Revue internationale d'études canadiennes, (41), 99-135. https://doi.org/10.7202/044164ar

Slowey, G. (2008). Navigating neoliberalism selfdetermination and the Mikisew Cree First Nation. UBC Press.

Stevenson, W. (1999). Colonialism and First Nations Women in Canada. In Scratching the Surface: Canadian Anti-Racist Feminist Thought. Toronto, ON: Women's Press.

Vowel, C. (2016). Indigenous writes: A guide to first nations, métis, and inuit issues in canada.

Werlhof, C. von. (2007). No Critique of Capitalism Without a Critique of Patriarchy! Why the Left Is No Alternative. Capitalism Nature Socialism, 18(1), 13-27. 